\title{
Thermal Conductivity Enhancement of Iraqi Origin Paraffin Wax by Nano-Alumina
}

\author{
Miqdam T. Chaichan* Rasha Mohammed Hussein** \\ Aida Mohammed Jawad*** \\ *Energy and Renewable Energies/ University of Technology \\ **Department of Mechanical Engineering/University of Technology \\ ***The Middle Technical University \\ *Email: 20185@uotechnology.edu.iq \\ **Email: mechanicalflower99@yahoo.com \\ ***Email: aida200899@yahoo.com
}

(Received 7 November 2016; accepted 22 February 2017)

https://doi.org/10.22153/kej.2017.02.003

\begin{abstract}
Paraffin wax is utilized for the heat storage applications taking advantage from the high stored latent heat during the phase change (from solid to fluid) period. What isn't right with this procedure is that the wax has a little heat transfer rate because of its low thermal conductivity. The thermal conductivity improvement of the paraffin wax has been examined utilizing nano-material with high thermal conductivity. In the recent study, $\left(\mathrm{Al}_{2} \mathrm{O}_{3}\right)$ nanoparticles with weights of 1,2 , and $3 \%$ of the paraffin wax were added to the paraffin wax. The Iraqi paraffin wax accessible at the local markets was utilized as a phase change material (PCM).

Many properties of the wax were changed due to the addition of nanofillers. The wax color was changed from light brown to white. The thermal conductivity of the paraffin wax was expanded by increasing the additional nanoparticles extent with $37.1,42.3$ and $60.32 \%$ for 1,2 and $3 \%$ added nano- $\mathrm{Al}_{2} \mathrm{O}_{3}$ compared to pure wax conditions. The subsequent change in the thermal conductivity of the paraffin wax makes it reasonable for the use in thermal storage applications.
\end{abstract}

Keywords: Latent heat, Nano-alumina, Paraffin wax, Thermal storage,

\section{Introduction}

The world's vitality circumstance came to an intersection, and the subject of whether there is a different option to the small oil assets or not [1]. The ascent in oil costs demonstrates the recorded decay of oil assets. The renewable energy sources, for example, nuclear power, solar energy, wind energy, and other renewable energies, as hydrogen fuel cells can get to be feasible contrasting options to fossil fills later on. Many valuable studies upheld the assessment that the end of the oil time is coming following a couple of decades [2]. With the unpredictability of the issue, the affirmation of this suspicion is far with the advancement of innovations used to produce oil and gas in various parts of the world [3]. To exploit solar energy is an impediment to specialists, as the solar radiation oscillates with the time and the dilemma of using it around evening hours. In this way, enhancing the thermal storage will diminish the effect of sunlight oscillation. The improvement in the energy storage of any system will increase its effectiveness and expand the consistent quality, and it assumes a critical part in keeping up the delivered energy [4].

The phase change materials are utilized to store thermal energy in solar energy applications. Variable phase change materials (PCM) have high latent heat storage capacities at the stage of phase 
change period from a solid to a fluid state, or from the fluid to the solid state. During this process, this material can store around 5 to 14 times the energy per unit volume, contrasted to the sensible heat storage materials, such as water, stone masonry, or rock.

Its low thermal conductivity portrays paraffin wax as other PCMS. This character limits the absorption and energy release rate. Many researchers have utilized variable sorts of fillers with high thermal conductivity to enhance the effective thermal conductivity of the phase change material. Fukai abused ceramic powder fillers and graphitic carbon fiber [5], Pincemin utilized graphite particles [6], Kim used peeled graphite as a part of his works [7], and Elgafy employed carbon nanofibers [8].

Current nanomaterials show physical and chemical properties contrast essentially when compared to the base mass structure [10]. The generation of various sorts of nanoparticles has ended up less demanding as a result of the fast advance in nanotechnology [11], mechanical and electronic building, and current procedures [12 and 13]. The higher thermal conductivity of the nanomaterials created from metals or metal oxides can be utilized with low conductivity materials as PCMs to improve its thermal conductivity [14]. A higher thermal conductivity can be accomplished at smaller nanomaterials size. The enhanced of thermal conductivity of PCMS causes advancements in its thermal qualities [15].

Wang figured out how to include nanomaterials for paraffin wax without bringing about any surface strain. The outcomes demonstrated that the expansion of nano- $\mathrm{TiO}_{2}$ in paraffin wax bringing on an adjustment in the thermal limit of the phase change material. The thermal conductivity of the wax additionally expanded plainly [16].

Fan researched the impact of including different extents of carbon nanofillers on the courier and energy storage and thermal properties of materials utilizing paraffin (PCMS). The thermal capacity of the formed material was slightly less with the nano-fillers addition; however, it has no impact on the temperature of the phase change. The outcomes demonstrated that the thermal conductivity of the PCMS nanocomposite increments with the expansion of the extent of fillers. Likewise, the relative change in the thermal conductivity relies upon the size and state of the added nanoparticles material [17]. Chaichan added two types of nano materials to the paraffin wax in variable mass fractions. $\mathrm{Al}_{2} \mathrm{O}_{3}$ and $\mathrm{TiO}_{2}$ were used to improve the thermal conductivity of the used PCM. The results indicated that thermal conductivity was improved with increasing the nanofillers mass fraction. The results revealed significant enhancement in the wax's charging and discharging period which was reduced with the addition of nanofillers [18]. The use of nano materials-paraffin wax composite gets wider interest in different applications, especially those related to the uses of solar thermal applications [19 \& 22].

The present study demonstrates the test examination of the performance enhancement due to the expansion of $\mathrm{Al}_{2} \mathrm{O}_{3}$ nanoparticles in the paraffin wax in various weights. The essential objective of this study is to assess the best proportion of nanoparticles that can be added to Iraqi paraffin wax to improve its thermal conductivity.

\section{Experimental Setup 2.1. Experimental Procedure}

The Iraqi paraffin wax was picked as PCM in the present study. It was selected due to its nominal melting point around $45^{\circ} \mathrm{C}$. Table 1 gives the details of the thermal and physical properties of the utilized wax. Nano-Alumina with grain size from 30 to $60 \mathrm{~nm}$ was used in this work. Table 2 demonstrates the details of the suppliers and properties of this material. These materials were chosen as a result of its accessibility and low costs; and were utilized with no additional purification procedures as got from the supplier. The technique for blending the wax with nanoparticles can be partitioned into five phases:

1. Pre-dissolving of unadulterated PCMs (as they received by the provider), it was melted to perform the homogeneous immaculate material. The fluid paraffin has been filled in Vials to facilitate the handling in the next stages. The material has been chilled off at room temperature; the paraffin wax was premelted and degassed in a vacuum stove at $105^{\circ} \mathrm{C}$ for 3 hours.

2. The nano-material and the paraffin wax were weighed to prepare the correct samples. The nano-fillers samples with mass fractions of 1,2 and $3 \%$ wt. were prepared.

3. The nano-material was dried at the same condition of the wax in the oven.

4. The samples of nano-Al2O3- PCM prepared using a melting mixing procedure. At first, the nanomaterial added to the molten wax with required percentage, and strong shear mixing with a magnetic stirrer for 15 min was used to 
mix the nano-Al2O 3 totally. This process was followed by an intense shaking using an ultrasonic shaker for five hours. The used ultrasonic shaker used type AlabTech (EXXX_1000), which picture is illustrated in Fig. 1. The process was conducted by putting the required nano- alumina fraction with the wax in a closed vessel immersed in $65^{\circ} \mathrm{C}$ hot water. Each sonication run of the devise was set to be 99 minutes. The samples temperatures were maintained at $65{ }^{\circ} \mathrm{C}$ during the mixing process to confirm the liquid phase of the wax.

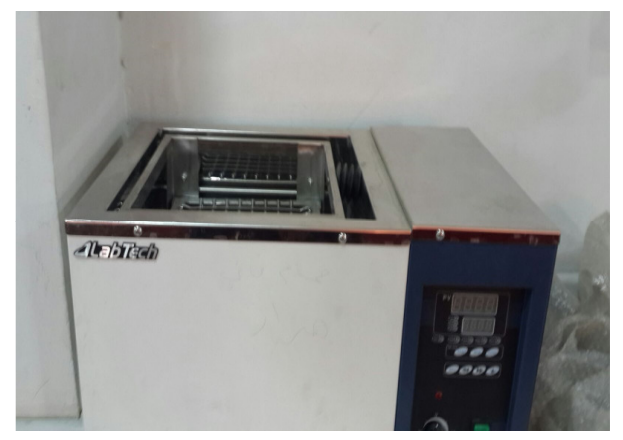

Fig. 1. Ultrasonic shaker type AlbaTech (EXXX1000).

After the complete mixing of wax and nano$\mathrm{Al}_{2} \mathrm{O}_{3}$, it was followed by the solidification process. The mixture was poured in a circular template with dimensions of $2 \mathrm{~cm}$ dia., and then was allowed to solidify freely at room temperature $\left(25^{\circ} \mathrm{C}\right)$ to form a solid paraffin wax. This solidification process completed at about three hours.

Table 1,

Thermo-Physical Properties for the Iraqi Paraffin Wax [18]

\begin{tabular}{lll}
\hline Material properties & & \\
\hline Melting temperature & $\left({ }^{\circ} \mathrm{C}\right)$ & $44{ }^{\circ} \mathrm{C}$ \\
Latent heat of fusion & $(\mathrm{kJ} / \mathrm{kg})$ & 190 \\
Solid density & $\left(\mathrm{kg} / \mathrm{m}^{3}\right)$ & 930 \\
Liquid density & $\left(\mathrm{kg} / \mathrm{m}^{3}\right)$ & 830 \\
Thermal conductivity & $\left(\mathrm{W} / \mathrm{m}^{\circ} \mathrm{C}\right)$ & 0.21 \\
Specific heat (Solid) & $\left(\mathrm{kJ} / \mathrm{kg}{ }^{\circ} \mathrm{C}\right)$ & 2.1 \\
Specific heat (Liquid) & $\left(\mathrm{kJ} / \mathrm{kg}{ }^{\circ} \mathrm{C}\right)$ & 2.1 \\
\hline
\end{tabular}

Table 2,

The suppliers and the used nano-fillers specifications

\begin{tabular}{ll}
\hline Item & $\mathbf{A l}_{2} \mathbf{O}_{3}$ specifications \\
\hline Manufacturer & Yurui Chemical Co., Ltd \\
Appearance & White powder \\
Assay & $99.99 \%$ \\
PH value & 7.5 \\
Crystal and Type & $\mathrm{a}$ \\
Grain size nm & $30-60 \mathrm{~nm}$ \\
bulk density \% & 0.43 \\
Loss on drying $\% \leq$ & 0.21 \\
Sulfated assay \% & 0.42 \\
$\mathrm{Fe} \leq \mathrm{ppm}$ & $\leq 0.005 \%$ \\
$\mathrm{Si} \leq \mathrm{ppm}$ & $\leq 0.003 \%$ \\
$\mathrm{Mg} \leq \mathrm{ppm}$ & $\leq 0.001 \%$ \\
\hline
\end{tabular}

\subsection{Experimental Instruments}

The following instruments were used in the tests:

1. The scanning electron microscopy (SEM) was used to display the surface micrographs of representative wax-nano $\mathrm{Al}_{2} \mathrm{O}_{3}$ samples. Fig 2 shows the main parts of the SEM that is the electron column, detectors, scanning system, and vacuum system, display, and electronics controls. The Electron microscopy can generate the electron beam on the surface of the sample with a size spot up to $10 \mathrm{~nm}$ diameter, and holds the remains sufficient current to form an acceptable image.

2. Hot Disk Thermal Constants Analyzer (Fig. 3) was used to measure the thermal conductivity of the samples. This device has a sensor plane passing hot consists of an electrically conducting pattern etched into the chip of thin nickel. This spiral is located between two sheets of insulation Mica material. When the thermal conductivity measurement is performed, the aircraft sensor hot disk is fixed between two pieces of the sample facing the sensor surface. By passing an electric current high enough to cause an increase in the sensors temperature, and is at the same time, recording the temperature increase with time.

Every test was repeated three times and the average was taken as the representative reading. The standard deviations of the data found to be less than $2 \%$ for the measurements.

\subsection{Test Procedure}

The tests began by setting up the wax tests. The second step was to get quick examples of 
nano-filler and wax suspensions. After the preparing the specimens, the thermal conductivity tests were begun utilizing Hot Disk Thermal Constants Analyzer. Both the softening and cooling practices were tried by warming the specimens in a compartment to $65^{\circ} \mathrm{C}$ and the abandon it to cool by natural convection in the air which its temperature was kept up at $25^{\circ} \mathrm{C}$. The wax and wax-nano composite tests temperature were measured and recorded amid every period. The outcomes were analyzed and discussed.

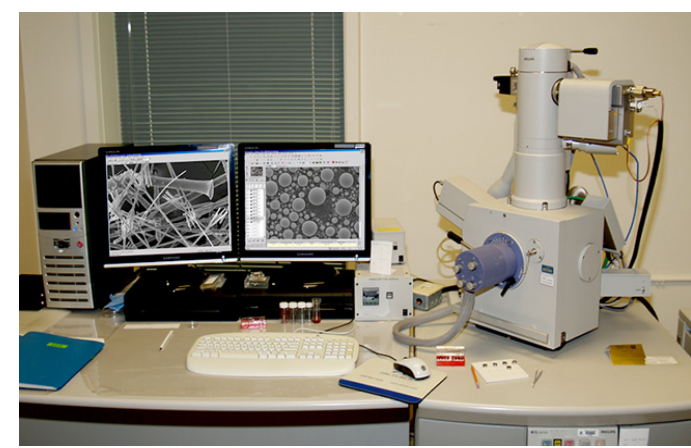

Fig. 2. The scanning electron microscopy (SEM).

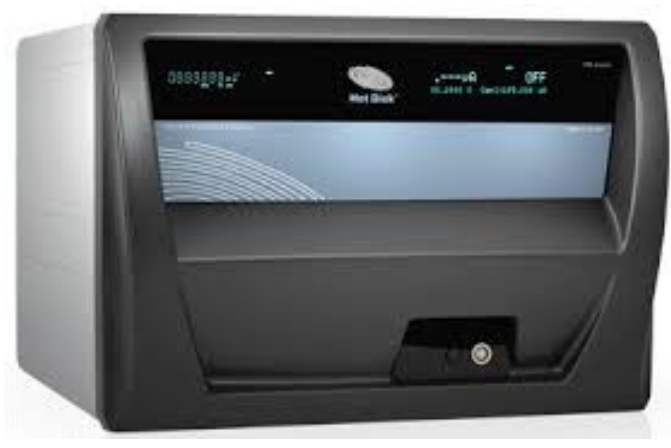

Fig. 3. Hot Disk Thermal Constants Analyzer.

\section{Results and Discussion}

The mixing of nanoparticles with wax results in a change in the color of the wax as shown in Fig. 4 (A and B). The color of the wax has turned from light brown (Fig. 4 A) to faint white color (Fig. $4 \mathrm{~B}$ ). The proper mixing of the material with nanoparticles means the nano- $\mathrm{Al}_{2} \mathrm{O}_{3}$ entered within the paraffin wax composition thus changing its characteristics. Among these features is the wax color. The color of the wax changing gives a clear indication of good mixing between the nanoparticles and wax. The nano-wax composite's color was affected slightly by the nano-alumina fraction variation.
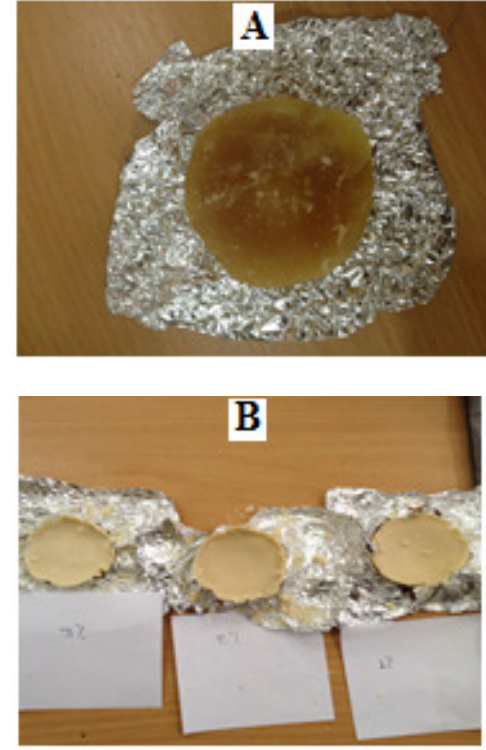

Fig. 4. (A) The paraffin wax before mixing with nano- $\mathrm{Al}_{2} \mathrm{O}_{3}$ and $(\mathrm{B})$ after the mixing

Fig. 5 represents the wax-nano $\mathrm{Al}_{2} \mathrm{O}_{3}$ suspension surface nature as it seems by the SEM scanning. The figure indicates that the nanoalumina-paraffin wax has non porous structure. It appears as one phase shape of the structure in (Fig. 5A), and any difference may seem in Figs. 5 $\mathrm{B} \& \mathrm{C}$ are due to the non-crystallite between wax and nano- $\mathrm{Al}_{2} \mathrm{O}_{3}$. The figures reveal acceptable dispersion of the nanomaterial into the wax. This dispersion at $100 \mathrm{~nm}$ scale was with few nano $\mathrm{Al}_{2} \mathrm{O}_{3}$ agglomerations, but it has a strong interaction between wax and the nanoparticles. The distributions at $50 \mathrm{~nm}$ scale (Fig. 5 B) and 20nm range (Fig.5 C) manifest strong interaction between both materials. 

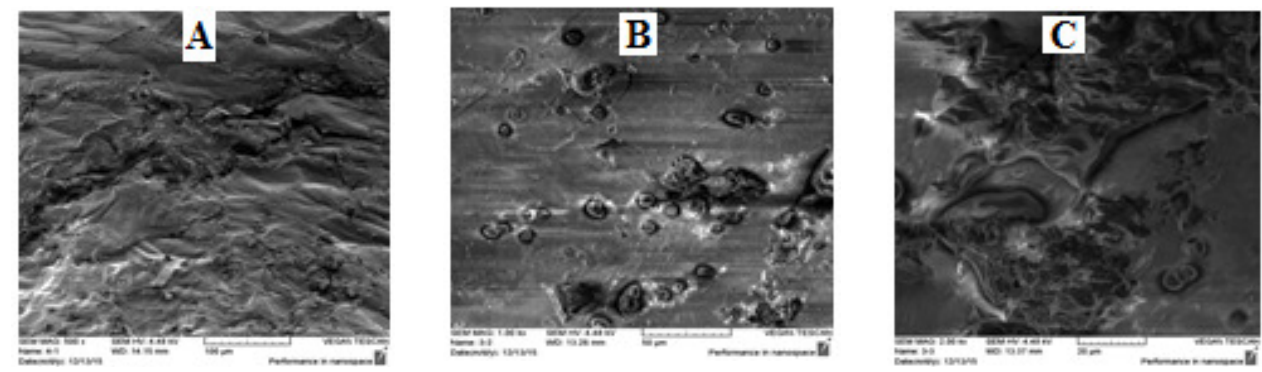

Fig. 5. scanning emission microscopic test (SEM) of the paraffin wax-nano $\mathrm{Al}_{2} \mathrm{O}_{3}$ suspension

The temperature impact on the thermal conductivity of the paraffin wax and its nano$\mathrm{Al}_{2} \mathrm{O}_{3}$ composites is outlined in Fig. 6. Adding nano-alumina to the wax increased its thermal conductivity as the figure reveals. The phenomenon of higher thermal conductivity of the nano- $\mathrm{Al}_{2} \mathrm{O}_{3}-\mathrm{PCM}$ composite than the case of wax alone resulted from lower thermal resistance. Also, the figure clearly shows that the thermal conductivity of the tested materials is temperature dependent, as its thermal conductivity decreased with increasing temperature. The paraffin thermal conductivity achieved its insignificant at the melting point, and after this stage, it came back to rise. The paraffin wax thermal conductivity was influenced by the expansion of nano- $\mathrm{Al}_{2} \mathrm{O}_{3}$. The nano- $\mathrm{Al}_{2} \mathrm{O}_{3}$ expansion enhanced the heat exchange rates by $37.1,42.3$ and $60.32 \%$ for 1,2 and $3 \%$ added nano- $\mathrm{Al}_{2} \mathrm{O}_{3}$. The liquefying change period from solid to fluid brought on a decrease in the thermal conductivity through this time. Table 3 illustrates the experimental results.

Table 3,

The experimental results.

\begin{tabular}{lllll}
\hline $\begin{array}{l}\text { Temperature } \\
\left({ }^{\circ} \mathbf{C}\right)\end{array}$ & Paraffin wax & $\mathbf{P W + 1 \%}$ nano $\mathbf{A l}_{\mathbf{2}} \mathbf{O}_{\mathbf{3}}$ & $\mathbf{P W + 2 \%}$ nano $\mathbf{A l}_{\mathbf{2}} \mathbf{O}_{\mathbf{3}}$ & $\mathbf{P W}+\mathbf{3 \%}$ nano $\mathbf{A l}_{\mathbf{2}} \mathbf{O}_{\mathbf{3}}$ \\
\hline 25 & 0.08894 & 0.09382 & 0.099101 & 0.1073 \\
35 & 0.05817 & 0.076043 & 0.079022 & 0.091001 \\
45 & 0.037898 & 0.06109 & 0.0635 & 0.07102 \\
55 & 0.044367 & 0.0712 & 0.07327 & 0.087107 \\
65 & 0.047897 & 0.0782 & 0.079902 & 0.088108 \\
\hline
\end{tabular}

Fig. 7 demonstrates that the nanoparticles enhanced the thermal conductivity of the paraffin wax yet this upgrade was changing with the additional nano- $\mathrm{Al}_{2} \mathrm{O}_{3}$ fraction. Gharagozloo [23] presented a relation of the relative thermal conductivity improvement by the condition:

Relative improvement $=(\mathrm{k}-\mathrm{ko}) / \mathrm{ko}$

This relation quantitatively connects the capability of thermal conductivity increment with the nanomaterial quantity. Nano- $\mathrm{Al}_{2} \mathrm{O}_{3}$-wax suspension accomplished an extensive change. It is hard to compare between various literatures findings because of the usage of variable paraffin wax types and nano-particle sizes.

Fig. 7 shows a comparison between the present results and the data reported in the literature. Enhancement in the thermal conductivity is evident whatever the type of the wax depending on the nano- $\mathrm{Al}_{2} \mathrm{O}_{3}$ quantity added with the addition of other parameters as the nanomaterial size, shape, and distribution figure. Arusu [24] improved the paraffin wax by adding nanoalumina particles and compared the variation in thermal conductivity with pure paraffin wax.

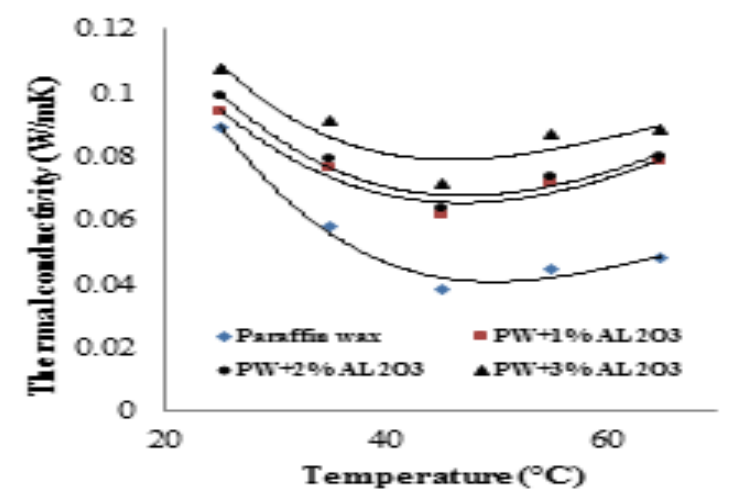

Fig. 6. Thermal conductivity during the temperature variation for the wax and nano- $\mathrm{Al}_{2} \mathrm{O}_{3}$ wax composites. 


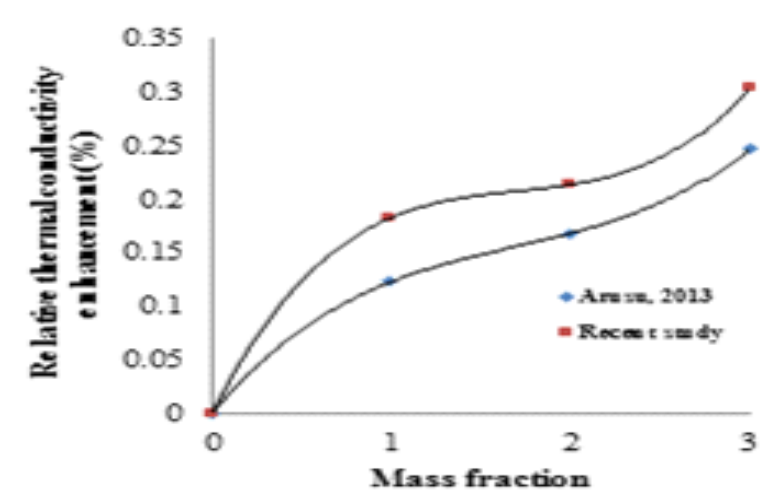

Fig. 7. Relative enhancement in thermal conductivity due to the added nano-fillers.

The relative enhancement in the thermal conductivity in Arusu case was lower than that of the recent study. This variation can be returned to the used paraffin wax difference. Arusu used a wax with $321^{\circ} \mathrm{C}$ melting point while the recent study used $45^{\circ} \mathrm{C}$ melting point wax. Table 4 lists the thermal conductivity relative enhancements for the Arusu and recent study.

Table 4,

The thermal conductivity enhancement variation for recent study and Ref. [24]

\begin{tabular}{lll}
\hline $\begin{array}{l}\text { Mass } \\
\begin{array}{l}\text { Fraction } \\
(\%)\end{array}\end{array}$ & $\begin{array}{l}\text { Recent study } \\
\text { thermal } \\
\text { conductivity } \\
\text { enhancement } \\
\text { rate (\%) }\end{array}$ & $\begin{array}{l}\text { Arusu [20] thermal } \\
\text { conductivity } \\
\text { enhancement rate } \\
(\%)\end{array}$ \\
\hline 0 & 0 & 0 \\
1 & 0.1817 & 0.122 \\
2 & 0.21237 & 0.167 \\
3 & 0.303 & 0.246 \\
\hline
\end{tabular}

\section{Conclusions}

In this study, the nano- $\mathrm{Al}_{2} \mathrm{O}_{3}$ particles were blended with an Iraqi paraffin wax to create a composite phase change materials (PCM) described with high latent heat and high thermal conductivity. The produced material had many properties changed from the first one. The material shading has been modified from chestnut to white. The SEM test demonstrated a decent scattering of the nano- $\mathrm{Al}_{2} \mathrm{O}_{3}$ in the wax. The thermal conductivity was expanded with the expansion in the nano-molecule mass division. The relative improvement with mass segment increment was $60.32 \%$ for $3 \%$ mass portion expansion of nano- $\mathrm{Al}_{2} \mathrm{O}_{3}$. The other published papers results showed some minor contrasts because of the utilized wax properties and to the employed nano- $\mathrm{Al}_{2} \mathrm{O}_{3}$ size and shape.

\section{Referances}

[1] Al-Maamary H M S, Kazem H A and Chaichan M T, Changing the energy profile of the GCC States: A review, International Journal of Applied Engineering Research, vol. 11, No. 3, pp. 1980-1988, 2016.

[2]BP. BP Statistical Review of World Energy June 2012. IOC statistical report, London: BP, 2012.

[3] Fitzpatrick, M., Assessment of climate change impacts on key terrestrial ecosystems and species in the Arabian Gulf countries, Technical Concept Note prepared for the Phase II Work Programme on Climate Change Vulnerability and Adaptation, EAD, 2012.

[4] Sharma A, Tyagi V V, Chen C R, Buddhi D, Review on thermal energy storage with phase change materials and applications, Renewable and Sustainable Energy Reviews, vol. 13, pp. 318-345, 2009.

[5] Fukai J, Kanou M, Kodama Y, Miyatake O, Thermal conductivity enhancement of energy storage media using carbon fibers, Energy Convers Manage., vol. 41, pp. 1543-1556, 2000.

[6] Pincemin S, Olives R, Py X, Highly conductive composites made of phase change materials and graphite for thermal storage, Solar Energy Materials and Solar Cells, vol. 92, pp. 603-613, 2008.

[7] Kim S, Drzal L T, High latent heat storage and high thermal conductive phase change materials using exfoliated graphite nanoplatelets, Solar Energy Materials and Solar Cells, vol. 93, pp. 136-142, 2009.

[8] Elgafy A, Lafdi K, Effect of carbon nano-fiber additives on thermal behavior of phase change materials, Carbon, vol. 43, pp. 3067-3074, 2005.

[9] Abdel-Hameed S A M, Margha F H, Preparation, crystallization behavior and magnetic properties of nanoparticles magnetic glass-ceramics in the systems $\mathrm{Fe} 2 \mathrm{O} 3-\mathrm{CoO}-$ $\mathrm{MnO} 2, \mathrm{Fe} 2 \mathrm{O} 3-\mathrm{NiOMoO} 3$ and $\mathrm{Fe} 2 \mathrm{O} 3-\mathrm{CoO}-$ V2O5. Journal of Non-Crystalline Solids, vol. 358, No. 4, pp. 832-838, 2012.

[10] Cabeza L F, Gutierrez A, Barreneche C, Ushak S, Fernández A G, Fernádez A I, Grágeda $\mathrm{M}$, Lithium in thermal energy 
storage: A state-of-the-art review, Renewable and Sustainable Energy Reviews, vol. 42, pp. 1106-1112, 2015.

[11] Cannio M, Bondioli F, Mechanical activation of raw materials in the synthesis of $\mathrm{Fe} 2 \mathrm{O} 3$ $\mathrm{ZrSiO} 4$ inclusion pigment, Journal of the European Ceramic Society; vol. 32, No. 3, pp. 643-647, 2012.

[12] Zhang D M, Zang C H, Zhang Y S, Han Y H, Gao C X, Yang Y X, Electrical property of nano-crystalline gamma-Fe2O3 under high pressure, Physical B-Condensed Matter, vol. 407, No. 6, pp.1044-1046, 2012.

[13] Fan G, Li H, Cao L, Shan F, Preparation and thermal properties of form-stable palmitic acid/active aluminum oxide composites as phase change materials for latent heat storage, Materials Chemistry and Physics, vol. 137, No. 9, pp. 558-564, 2012.

[14] Gil A, Barreneche C, Moreno P, Solé C, Fernundez A I, Cabeza L F, Thermal behavior of D-mannitol when used as PCM: Comparison of results obtained by DSC and in a thermal energy storage unit at pilot plant scale, Applied Energy, vol. 111, pp. 11071113, 2013.

[15] Giro-Paloma J, Rayon E, Roa J J, Martinez M, Fernandez A I, Effect of the filler on the nano mechanical properties of polypropylene in contact with paraffinic phase change material, European Polymer Journal vol. 63, pp. 29-36, 2015.

[16] Wang J, Xiea H, Guo Z, Lia Y, Improved thermal properties of paraffin wax by the addition of $\mathrm{TiO} 2$ nanoparticles, Proceedings of the 2nd International Workshop on Heat Transfer Advances for Energy Conservation and Pollution Control (IWHT2013), October 18-21, 2013.

[17] Fan L W, Fang X, Wang X, Zeng Y, Xiao Y Q, Yu Z T, Xu X, Hu Y C, Cen K F, Effects of various carbon nano-fillers on the thermal conductivity and energy storage properties of paraffin-based nano-composite phase change materials, Applied Energy, vol. 110, pp. 163172, 2013.
[18] Chaichan M T, Kamel S H, Al-Ajeely A N $\mathrm{M}$, Thermal conductivity enhancement by using nano-material in phase change material for latent heat thermal energy storage systems, SAUSSUREA, vol. 5, No. 6, pp. 4855, 2015.

[19] Zeng J L, Gan J, Zhu F R, Yu S B, Xiao Z L, Yan W P, Zhu L, Liu Z Q, Sun L X, Cao Z, Tetradecanol/expanded graphite composite form-stable phase change material for thermal energy storage, Solar Energy Materials \& Solar Cells, vol. 127,pp. 122128, 2014.

[20] Chaichan M T, Al-Hamdani A H, Kasem A $\mathrm{M}$, Enhancing a Trombe wall charging and discharging processes by adding nano-Al2O3 to phase change materials, International Journal of Scientific \& Engineering Research, vol. 7, No. 3, pp: 736-741, 2016.

[21] Rathod M K, Banerjee J, Thermal stability of phase change materials used in latent heat energy storage systems: A review, Renewable and Sustainable Energy Reviews, vol. 18, pp. 246-258, 2013.

[22] Abdin Z, Alim M A, Saidur R, Islam M R, Rashmi W, Mekhilef S, Wadi A, Solar energy harvesting with the application of nanotechnology, Renewable and Sustainable Energy Reviews, vol. 26, pp. 837-852, 2013.

[23] Gharagozloo P E, Eaton J K, Goodson K E, Diffusion, aggregation, and the thermal conductivity of nanofluids, Applied Physical Letters, vol. 93, No. 10, pp. 103-110, 2008.

[24] Arasu V, Mujumdar A S, Numerical study on melting of paraffin wax with $\mathrm{Al} 2 \mathrm{O} 3$ in a square enclosure, International Communications in Heat and Mass Transfer, vol. 39, pp. 8-16, 2013. 


\title{
تحسين الموصلية الحرارية لشمع البرافيين العراقي المنشأ باضافة الألومينا النانوية المنشأ
}

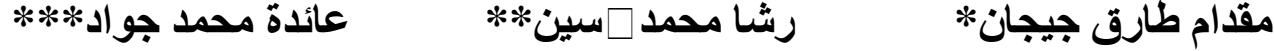

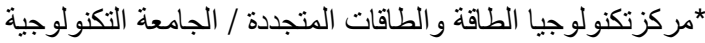

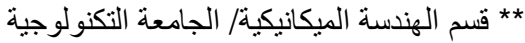

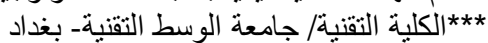 \\ * البريد الاكتروني: Uotechnology.edu.iq \\ mechanicalflower99@yahoo.com:البريد الالكتروني: الإكنروني:

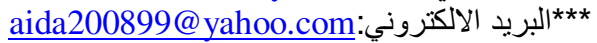

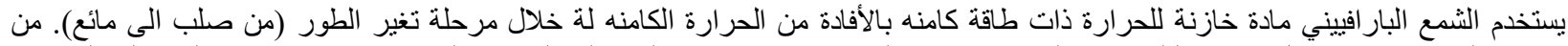

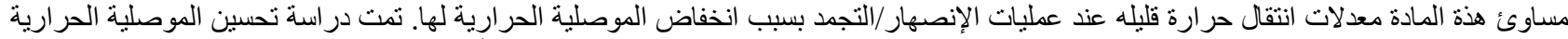

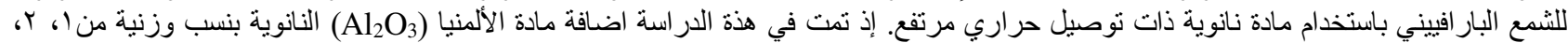

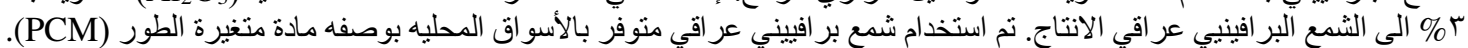

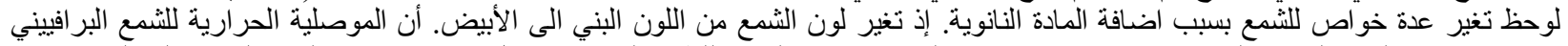

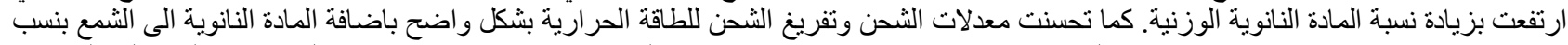

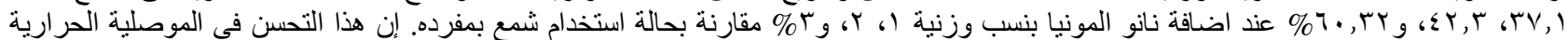

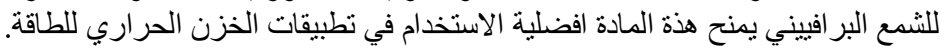

